\title{
Dominant Personalities in Board Committees, Company Characteristics, and Internet Environmental Disclosure by Malaysian Listed Companies
}

\author{
ALI SALEH ALARUSSI \\ MOHAMAD HISYAM SELAMAT \\ College of Business \\ Universiti Utara Malaysia
}

\begin{abstract}
This paper investigates the determinants of internet environmental disclosure (IED) amongst Malaysian listed companies. Ten variables have been tested using data collected from 170 Malaysian listed company websites, namely, dominant personalities in the audit committee, chairman of audit and nomination committees, dominant personalities in the audit and nomination committees, internationality, leverage, foreign shareholders, level of technology, firm age, number of shareholders, and listing status. It was found that internationality, foreign shareholders, level of technology, firm age, number of shareholders, and listing status are significantly affected by the level of IED. However, dominant personalities in the audit committee, chairman of audit and nomination committees, dominant personalities in the audit and nomination committees, and leverage did not show a significant relationship with the level of IED in Malaysia. The study provided some evidence to support signaling theory, shareholder accountability theory, and cost and benefit hypothesis in relation to internet disclosure.
\end{abstract}

Keywords: Determinants; internet environmental disclosure; listed companies.

\begin{abstract}
ABSTRAK
Artikel ini mengkaji penentu-penentu bagi pendedahan maklumat persekitaran melalui internet dalam kalangan syarikat-syarikat Malaysia yang tersenarai. Sebanyak sepuluh pemboleh ubah telah dianalisa dengan menggunakan data daripada 170 laman web iaitu personaliti dominan dalam jawatankuasa audit, pengerusi jawatankuasa audit dan perlantikan, personaliti dominan dalam jawatankuasa audit dan perlantikan, keantarabangsaan, leverej, pelabur luar, tahap teknologi, usia syarikat, bilangan pemegang saham dan status penyenaraian. Daripada kajian ini didapati bahawa faktor keantarabangsaan, pelabur luar, tahap teknologi, usia syarikat, bilangan pemegang saham dan status penyenaraian mempengaruhi tahap pendedahan maklumat persekitaran melalui internet secara signifikan. Bagaimanapun personaliti dominan dalam jawatankuasa audit, pengerusi jawatankuasa audit dan perlantikan, personaliti dominan dalam jawatankuasa audit dan perlantikan serta leverej tidak mempunyai perhubungan yang signifikan dengan pendedahan maklumat persekitaran melalui internet. Dapatan kajian ini menyokong teori pemberitahuan, teori kebertanggungjawaban pemegang saham dan hipotesis kos dan faedah berkaitan dengan pendedahan melalui internet.
\end{abstract}




\section{INTRODUCTION}

The rapid growth of internet technology has provided a platform for the companies to disclose their financial and non-financial information directly and instantly to worldwide users. The level of internet usage has increased over the last couple of years in the financial markets (Wagenhofer, 2003). Based on the findings of a survey conducted by the National Institute of Investor Relations, investment relations departments are under pressure to fulfil the increasing demands of investors for online information (Sriram \& Laksmana, 2006). This phenomenon has attracted many academic researchers in the disclosure field. It is argued that internet reporting is an efficient instrument to communicate information to external users at a minimum cost. In other words, internet reporting provides greater and quicker access to corporate activities' information which is available through interactive and connected reports (Lev \& Zarowin, 1999; Ettredge, Richardson, \& Scholz, 2002). This facilitates investors in decision-making processes.

Environmental information is one type of non-financial information that is considered by companies to be disclosed on the Internet. This is due to public awareness on environmental issues. Environmental information has been defined by Ahmed, Billings, Morton, and StanfordHarris (2002) as a division of corporate social responsibility, which includes information such as environmental activities, waste management, recycling programmes, environment control, and other environmental issues. Dunlap and Scarce (1991) surveyed public opinion on environmental issues and found that the public views businesses and the industry as major contributors to environmental problems. They also argued that many people may avoid buying products from companies that have poor environmental records.

However, disclosing environmental information by using printed media is costly compared to internet media (Lodhia, 2002). This highlights the importance of capitalising internet technology in environmental information disclosure. The benefits of IED include mass communication, global-reach abilities, timelines and updateability, presentation flexibility and visibility, navigational ease, increased information, cost benefits, integration, and push information (Debreceny, Gray, \& Rahman, 2002; Lodhia, 2004). In addition, stakeholders can obtain environmental information such as environmental costs, necessities, incidents, and liabilities (Lodhia, 2002; Groff \& Pitman, 2004). All these benefits lead to low information asymmetry amongst users.

McIvor, McHugh, and Cadden (2002) argued that internet technology encourages transparency as it provides an economical platform to the organisations to change business culture that is critical in facing a rapidly changing environment. Morris and Gray (2005) argued that transparency is a good mechanism for helping investors in making decisions and better allocating resource for an optimum return on investment. This in turn leads to efficient capital market and better economic growth and social welfare (Meek \& Thomas, 2003). In addition, transparency is one of corporate governance mechanisms that is essential for developing countries (Morris \& Gray, 2005).

The above phenomenon is evident from the increased level of IED amongst companies. For example, Jones, Alabaster, and Hetherington (1999) examined 275 companies across 21 sectors in 21 countries and found that $59 \%$ of them provide IED. This is also supported by the studies that were undertaken by Park (1999), Tilt (2001), and Isenmann and Lenz (2001). However, in Malaysia, the percentage of IED is low (Hassan, Jaffer, \& Johi, 1999; Healy \& Palepu, 2001; Ahmed et al., 2002; ACCA, 2002). This could lead to low transparency, in terms of the impact of industrial activities on the environment, amongst Malaysian companies. Low transparency, on the other hand, can reduce investors' confidence in the Malaysian economy and in turn could negatively affect Malaysian foreign and local direct investment (Gul \& Leung, 2004; Morris \& Gray, 2005). Thus this study intended to answer the following question: What are the determinants of IED in Malaysia?

The remainder of this paper is structured as follows. Section 2 provides an overview of IED development, while section 3 reviews the factors that affect IED. The research method is described in section 4 . Section 5 presents the results of this research. Finally, section 6 provides the conclusions, limitations, and recommendations for future research. 
The Development of Internet Environmental Disclosure

Jones et al. (1999) conducted a comparative study which examined 275 companies across 21 sectors in 21 countries. The results of the study showed that 163 companies provide some environmental information on their corporate websites. However, the provided information are directly translated or summarised from the hard copy version of their corporate environmental reports. So it can be concluded that these companies are not taking full advantage of the technology to make environmental information more interactive and active on the website. They suggested that companies should shift their view from point of distribution of information to a unique website presentation. This could be undertaken by using facilities such as audio and video. These views are also supported by Esrock and Leichty (1998).

Lodhia (2002) argued that the demand for environmental information is increasing due to global recognition of the importance of environmental issues. This is evident from the calls to impose a separate environmental report instead of a section in the annual report. It is argued that the contents of annual reports do not reflect current social and environmental issues.

In Australia, the Financial Services Reform Act (FSRA) that has been introduced in March 2002 requires companies to disclose environmental information when they make investment decisions. This will entail parallel company disclosure (Hoggett \& Nahan, 2002). The United Kingdom legislative body also includes this requirement to a lesser extent. Similar moves are also being considered by Germany, France, Canada, and the European Commission.

Debreceny et al. (2002) argued that external environment has an important role in the level of internet disclosure. Two important environmental determinants are the level of internet usage by the public and the overall disclosure environment in the company's home country. With respect to the first determinant, if the use of internet is common in a country, the users will expect more company information to be placed on the Internet. Similarly, if the companies believe that there is a large internet audience amongst their domestic stakeholders, they are more likely to have higher level of internet reporting.
Al-Tuwaijria, Christensenb, and Hughes (2003) examined the association between environmental disclosure, environmental performance, and economic performance. The results showed a significant association between environmental performance and economic performance whereby extensive quantifiable environmental disclosures of specific pollution measures and occurrences lead to higher profit. In other words, the companies are aware of the long-term benefits when environmental impacts are being disclosed (Houlston \& Daoust, 2005).

Ahmad, Hassan, and Mohammad (2003) stated that there are several factors that motivate companies in disclosing environmental information. All these factors are related to the concept of organisational legitimacy that was developed by Lindblom, MacNeilage, and Studdert-Kennedy (1984). The first factor is to alleviate any expected loss by informing the stakeholders about the impact of environmental changes on the companies' performance. The second factor is to cover any environmental impairment due to companies' activities. By doing this, their reputation and image can be preserved. The third factor is to change public attention. In other words, the company that pollutes the environment through its production processes discloses information regarding recycling programmes so that public attention will be diverted to it rather than to environmental impairment.

Andrew (2003) examined the trend of IED amongst Australian companies. In this study, 64 websites of randomly selected Australian companies listed on the Australian Stock Exchange were visited. The results showed that the Internet is still not utilised to its full potential (including its interactive features) as there is no significant difference between internet reports and printed reports. In addition, the results showed that environmental disclosures are highly dependent on the industry. In short, the study argued that the Internet provides a huge opportunity to the companies to increase their environmental disclosures and eventually enhance the level of transparency.

Thompson and Zakaria (2004) stated that higher environmental disclosure is noticed when corporate environmental reporting standards from 
the International Organisation for Standardisation (ISO) are revealed - ISO 14000. A new ISO working group is currently working on ISO 14063 - Environmental Management: Environmental Communication.

However, there are just a few published studies about the state of environmental disclosure in Malaysia. Some of these studies were conducted as comparative studies such as Thompson (2002), and Ramasamy and Ting (2004) which compared Malaysia with Singapore. Other studies are related to the level of corporate social responsibility reporting (Nik Ahmad, Sulaiman, \& Siswantoro, 2003; Ahmad et al., 2003; Zulkifli, 2003; Thompson \& Zakaria, 2004). The main reason behind this phenomenon is that IED is still a voluntary exercise in Malaysia as well as in other countries (Ahmad et al., 2003). There is no particular standard or requirement either issued by the Malaysian Accounting Standard Board (MASB) or other regulatory bodies that necessitate companies to disclose such information. However, companies must consider the requirement stated under Paragraph 9 of MASB No. 1 which requires companies to disclose any other relevant, even though not mandated, information that users consider very important for their decision making (MASB, 1999).

To recapitulate, the trend of IED is very encouraging. This in turn creates the need to understand the determinants of IED; the descriptions of which are offered in the following section.

\section{The Determinants of Internet Environmental Disclosure}

A large number of studies in different countries has attempted to find out the determinants of IED. They came up with different determinants and factors that may affect the extent of disclosure. However there are no consistent results due to the different nature of studies. This study intended to examine the relationship between two groups of variables and the extent of IED by Malaysian listed companies. The first group of variables is dominant personalities in the board committees. This group includes three variables which are dominant personalities in the audit committee, chairman of audit, and nomination committees, and dominant personality in the audit, and nomination committees. The second group of variables is company characteristics, which includes seven variables namely internationality, leverage, foreign shareholders, level of technology, firm age, number of shareholders, and listing status.

\section{Dominant Personalities in the Audit Committee}

One of the basic goals of board of directors is its monitoring responsibility. However, specific roles are given to sub-committees. Kesner (1988) indicated that most essential board decisions originate at the committee level, such as audit committee. The audit committee aims to increase the integrity of the financial auditing process (Klein, 2002) and the quality of financial reporting (McMullen, 1996).

Motivated by recent regulatory requirements (Sarbanes-Oxley Act, 2002; Blue Ribbon Committee, 1999) that public companies are to disclose whether they have independent directors with financial expert in their audit committee, the impact of independent directors' financial expertise on the audit committee is selected as a corporate governance attribute contributing to the integrity of the financial reporting process. This regulatory requirement is motivated by the view that independent directors are more likely to use their expertise to detect and prevent opportunistic managerial behaviour that would benefit shareholders.

While different areas of director expertise may be valuable to the firm, corporate or financial expertise is an essential requirement for directors sitting on the audit committee to carry out their responsibilities successfully. In addition, as the audit committee competence is defined as a combination of independence and expertise (PriceWaterhouseCoopers, 2000), it is expected that if the chairman of the company is also the chairman of audit committee, the independence of audit committee will be negatively affected and as a consequence disrupts its duty. Since this relationship has not been tested in previous studies, this research has attempted to examine the impact of lack of independency in the audit committee on the extent of IED. Thus the following hypothesis was proposed:

\section{H1: $\quad$ The extent of environmental disclosure on the Internet is influenced if the chairman of board directors is also the chairman of audit committee in the company.}




\section{Chairman of Audit and Nomination Committees}

Given that independent directors' expertise is an important determinant of the extent of their monitoring effectiveness, an independent director with no financial background may be a good monitor but may not be capable of detecting earnings manipulations (i.e. earnings management). In contrast, an independent director with financial background is more knowledgeable with different forms of earnings manipulations (Xie, Wallace, \& Peter, 2003). The role of the nomination committee is to recommend candidates with an optimal mix of qualifications, skills, and experience to the board. The nomination committee also carries out annual evaluation on the effectiveness of the whole board. This type of work needs full independency as it involves various committees and directors' contributions to the effectiveness of decision-making process.

Due to the importance of audit and nomination committees in the decision-making process, this study has intended to examine the impact of having the same person as the chairman of both audit and nomination committees on the extent of IED. To ease this process, the following hypothesis was identified:

\section{H2: $\quad$ The extent of environmental disclosure on the Internet is influenced if the chairman of audit committee is also serving as the chairman of nomination committee in the corporation.}

\section{Dominant Personalities in the Audit and Nomination Committees}

Audit committees can contribute to internal monitoring by increasing the level of integrity to the financial auditing process (Klein, 2002). McMullen (1996) uncovered that the existence of audit committee relates positively to financial reporting quality. However, the existence of audit committee alone does necessarily lead to effective monitoring. Other factors should be considered when analysing the role of an audit committee in monitoring the management's behaviour and performance, such as directors' independence. Audit committees should be independent from the management to be able to conduct effective monitoring, leading to less opportunistic earnings management. An independent audit committee can potentially improve the quality and credibility of financial reporting (Guthrie \& Turnbull, 1995).

However, it is expected that this independency might be lower if the chairman of the company is also holding the position of chairman of both audit and nomination committees. As the disclosure decision is under the scrutiny of the chairman of the company, having that chairman as the chairman of both audit and nomination committees could negatively affect the extent of disclosure as it reduces internal monitoring and balance of power. This study has attempted to provide empirical evidence regarding this issue by examining the extent of voluntary environmental disclosure on the Internet if the chairman of board of directors is also the chairman of audit and nomination committees of the company. Thus the following alternative hypothesis is proposed:

\section{H3: $\quad$ The extent of environmental disclosure on the Internet is influenced if the chairman of board directors is also the chairman of audit and nomination committees in the company.}

\section{Internationality}

It is argued that once a company become famous and known globally, many foreign investors will invest in it to gain more profit. In this case, an international company has an opportunity to get capital from worldwide investors to finance its activities at a minimum cost. However, such company is required to disclose more financial and non-financial information for two reasons: (1) to eliminate an information asymmetry that a rises due to the existence of foreign users; and (2) to fulfill minimum regulation requirements of different countries that the company has operations, and thereby increase the number of stakeholders. This expectation is supported by Debreceny et al. (2002) who stated that companies try to lower their average cost of capital by listing on foreign exchanges. However, foreign listing extends the dispersion of shareholders, which in turn increases the information asymmetry between managers and shareholders. This is because foreign shareholders may face difficulties 
in understanding the disclosure rules of the company's home country.

The required report in any financial market is the annual reports. In this case, international companies have to disclose more information to fulfill the needs of various customers, shareholders, suppliers, investors, and others. Gray, Meek, and Roberts (1994) examined annual reports of 280 multinational companies in 1989 in the USA, UK, and Europe, and found that there is significant difference in financial reporting between international and local listed companies. Annual reports of multinational companies are more detailed than annual reports of local companies. It is argued that international companies disclose more information on the Internet than non-international companies due to the following reasons:

- Internet disclosure reduces disclosure costs because there is no need to involve printing media such as newspaper and journals, which are very expensive if many countries are involved (Marston \& Polei, 2004).

- Some users require similar information with others to make decisions and therefore it would be easy for them to use the Internet to get the required information especially when they are in different countries (Oyelere, Laswad, \& Fisher, 2003).

- As one company becomes multinational, it will be under the scruting of many interested investors who would like to optimise return on investment. According to them, multinational companies always implement best practices in every activity, such as internet reporting, and are more transparent in disclosing information than local companies. From the organisational perspective, multinational status provides an opportunity to lower cost of capital due to strong image and reputation amongst worldwide interested investors. Positive image and reputation cannot be created through asymmetry information. In other words, more disclosure is needed to alleviate asymmetry information and build strong image and reputation amongst investors. Since it is very difficult for multinational companies to know every interested investor in different countries, it is logical for them to utilise the Internet as a medium to disclose information since it provides global access at anytime (Marston, 2003).

Therefore, it is expected that the level of environmental disclosure will be higher in the multinational companies than local companies. This is because multinational companies have to show their environmental friendliness in order to create investors' acceptance and satisfaction by complying to environmental rules and regulations that are imposed by the host countries (Isenmann \& Lenz, 2001).

From the aforementioned discussion, it is necessary to include the element of internationality when studying the determinants of IED. Internationality is measured by using exportson-sales ratio (Garcia-Benau \& MonterreyMayoral, 1992; Raffournier, 1995) and number of subsidiaries (Cooke, 1989) in the previous studies. This study intended to use these descriptions and definitions for its international variable. Therefore, based on the above discussion, the identified hypothesis to be tested is as follows:

\section{H4: $\quad$ The extent of environmental disclosure on the Internet is positively related to the level of international activity of the company}

\section{Leverage}

It is argued that once a company uses a large amount of debt, a monitoring problem arises between stockholders and creditors. To alleviate this issue, the involved companies usually increase their level of voluntary disclosure for two reasons. The first reason is to show their payback capability to the shareholders. The second reason is to respond to the additional information required by the creditors including environmental information. Previous studies, however, found mixed results about the association between leverage and the extent of disclosure (Chow \& Boren, 1987; Garcia-Benau \& Monterrey-Mayoral, 1992).

Richardson and Welker (2001) argued that social and financial disclosures have similar determinants. Since there is association between leverage and financial disclosure, it is expected that a similar relationship could be established with the environmental disclosure. This is 
supported by Roberts (1992) who found that a high degree of debt to equity ratio would encourage one company to increase social activities and disclose more environmental information in order to please the creditors.

Although there is a positive association between financial leverage and the extent of voluntary social responsibility disclosure, Chow and Boren (1987) and Ahmed and Nicholls (1994) found no significant association between them. This difference occurs due to the fact that leverage is a relatively poor proxy to measure company risk (Dichev \& Skinner, 2002). However, Ahmad et al. (2003) argued that companies with lower leverage are likely to disclose more environmental information to ensure that its financial risk is always low.

Despite contradictory findings in the relationship between financial leverage and social responsibility disclosure, this study was still interested in examining it from the perspective of IED. This is due to critical role of leverage in influencing one company to disclose more information to please creditors. Previous studies had defined leverage as the percentage between debts to equity (Roberts, 1992; Katsuhiko, Akihiro, Yasushi, \& Tomomi, 2001). In this study, however, leverage was measured by comparing total liabilities with total assets (Haniffa \& Cooke, 2002; Laswad, Fisher, \& Oyelere, 2005; Alsaeed, 2005). Based on the above discussion, the study proposed the following hypothesis:

\section{H5: $\quad$ The extent of environmental disclosure on the Internet is related to leverage.}

\section{Foreign Shareholders}

Xiao, Yang, and Chow (2004) stated that, in general, foreign shareholders are more likely to face a higher level of information asymmetry and difficulty in accessing and understanding companies' corporate reports. This problem limits investors' ability to protect themselves from possible losses. Hence more information is required to mitigate that perception. This could be achieved through extensive voluntary disclosure. On the other hand, global dissemination of financial and environmental information is necessary to create a high level of transparency, which is important to foreign investors (Isenmann $\&$ Lenz, 2001). The above argument is supported by Haniffa and Cooke (2002) who found a significant positive relationship between foreign ownership and disclosure level. Therefore, the element of foreign ownership could be considered as a determinant of IED since this is a global issue. This variable will be measured by dividing total shares owned by foreigners with total number of issued shares (Haniffa \& Cooke, 2002). Based on the above discussion, the proposed hypothesis is as follows:

H6: $\quad$ The extent of environmental disclosure on the Internet is positively related to existence of foreign shareholders.

\section{Level of Technology}

Jensen and Meckling (1995) argued that the relationship between knowledge about industry and agency costs is significantly related. One of the factors that discourage companies from using the Internet is the need for recruiting experts to handle it. The experts will utilise information technology to develop the website and in turn disclose environmental information on the Internet (Lodhia, 2004). To effectively organise this process, a department of technology is usually established. Through internet reporting, the companies can reduce environmental information disseminating cost. Debreceny et al. (2002) examined the association between level of technology and the extent of voluntary disclosure through the Internet and found a significant relationship between them. In short, the element of level of technology is declared to be a determinant of IED. It is measured by using a dummy measurement. Thus the proposed hypothesis is as follows:

H7: $\quad$ The extent of environmental disclosure on the Internet is influenced by the level of technology.

\section{Company Age}

Generally, there are two opposite views about the effect of company's age on the level of disclosure. The first one was proposed by Ho and Wong (2001) who argued that company age is negatively affected by the level of disclosure. This is due to information asymmetry which is typically higher in new companies and therefore requires higher disclosure than the old ones. The 
second view was proposed by Hughes (1986) who argued that, according to signaling theory, old companies generally disclose more information in order to differentiate themselves from the new comer on the stock exchange. In addition, as the old companies have more control over the market, they are in a better position to provide reliable forecasts.

Alsaeed (2005) examined the extent of voluntary financial disclosure amongst Saudi listed companies and found that the age of the company has no significant impact on the level of disclosure. The result, however, is significant for the high-ranked companies. Camfferman and Cooke (2002) stated that the element of company age has a significant impact on the extent of internet disclosure due to the fact that old companies always develop and improve annual reports, and their level of disclosure over time.

From the aforementioned discussion, it is interesting to examine the relationship between the element of company age and the level of IED. Thus the identified hypothesis is as follows:

\section{H8: $\quad$ The extent of environmental disclosure on the Internet is influenced by the company age.}

\section{Number of Shareholders}

It is argued that number of shareholders is the most important determinant of IED. This is because disclosure media are selected based on cost and benefit analysis. Whenever the management finds that the cost of disclosure is higher than the expected benefits, other disclosure alternatives will be evaluated based on the element of extent of disclosure, type of information, and type of media. Therefore, in the case of firms that have a huge number of shareholders, it is expected that disclosure through the Internet is the best choice for them due to the high cost and limited spaces for paper-based media (Lodhia, 2004). The above argument has been empirically supported by the study conducted by Oyelere et al. (2003). Thus this study argued that the element of number of shareholders has a significant impact on the level IED in Malaysia. To ease this process the following hypothesis was proposed:

H9: $\quad$ The extent of environmental disclosure on the Internet is influenced by the number of shareholders.

\section{Listing Status}

In Bursa Malaysia, there are two types of boards which are main and second boards. On the main board, large corporations that have financial capital of more than RM60 million are listed (Yatim, Kent, \& Clarkson, 2006). The medium and small corporations are listed on the second board. It is expected that the corporations listed on the main board are more inclined to disclose more information on the Internet than those listed on the second board for several reasons. Firstly, there are a number of requirements that one company should fulfill if it would like to be listed on the main board and those requirements are not applicable to the second board (Wong, 1996). One of those requirements is that the company should be more transparent. Secondly, the competition among main board listed companies is stiffer than second board listed companies and thus the public eye is more critical toward them (Abdul Samad, 2002). This variable has not been examined in previous studies and therefore should be of interest to see whether the status of board in Bursa Malaysia has any influence on the level of internet disclosure. In other words, this study has intended to examine the impact of an organisation's listing status in Bursa Malaysia on the extent of IED. Therefore, the following hypothesis was proposed:

H10: $\quad$ The extent of environmental disclosure on the Internet is influenced by firm's listing status.

\section{RESEARCH DESIGN}

This study to examined the determinants of IED amongst Malaysian public listed companies. The data for this study was secondary in nature and derived from the information disclosed in the companies' websites. In total, 170 websites were randomly selected. This figure does not include financial companies because they have different regulations. In addition, two companies were excluded from the sample because they just show outlines in the analysis. A regression model was utilised to predict the relationship between variables of this study and this is in tandem with previous studies (Katsuhiko et al., 2001; Suda \& Kokubu, 1994; Park, 1999; Ahmad et al., 2003; Al-Tuwaijria et al., 2003). The measurement for each variable is illustrated in Table 1. 
Table 1: The Measurement of Variables

\begin{tabular}{|c|c|c|}
\hline No. & Variables & Measurement \\
\hline 1. & $\begin{array}{l}\text { Dominant personalities in the audit } \\
\text { committee }\end{array}$ & 1 , if the chairman of company is also the chairman of audit committee, otherwise 0. \\
\hline 2. & $\begin{array}{l}\text { Chairman of audit and nomination } \\
\text { committees }\end{array}$ & 1 , if the chairman of audit committee is also the nomination committee, otherwise 0. \\
\hline 3. & $\begin{array}{l}\text { Dominant personalities in the audit } \\
\text { and nomination committees }\end{array}$ & $\begin{array}{l}1 \text {, if the chairman of company is also the chairman of audit and nomination committees, } \\
\text { otherwise } 0 .\end{array}$ \\
\hline 4. & Internationality & export-on-sales \\
\hline 5. & Leverage & total of long liabilities divide by the total of assets \\
\hline 6. & Foreign shareholders & total number of shares held by foreign shareholders \\
\hline 7. & Level of technology & 1 if the firm has a technology department in its structure, otherwise 0 \\
\hline 8. & Company age & 1 , if the age of the firm is more than 20 years, otherwise 0 \\
\hline 9. & Number of shareholders & Total number of shareholders in the company \\
\hline 10. & Listing status & 1 if the company is listed on the main board, 0 if the company is listed on the second board \\
\hline
\end{tabular}

\section{Descriptive Statistics}

Descriptive statistics, such as frequency distributions, cross tabulations, and measures of central tendency represent the frequency of occurrence of each score value (Sekaran, 2002). The skewness and kurtosis ratios are also calculated to check whether dependent variable is normally distributed. According to Sekaran (2002), both skewness and kurtosis values must be between +/- 1 before one variable can be declared as normally distributed. Table 2 shows that the value of skewness and kurtosis of IED is 0.980 and 0.281 respectively. The standard errors of skewness and kurtosis values are 0.187 and 0.373 for IED, respectively. All these figures show that normality exists on the dependent variable, and therefore multiple regression analysis can be applied on them.

Table 2: Descriptive Statistics for Dependent Variable

\begin{tabular}{llll}
\hline \multicolumn{1}{c}{ Statistics } & IED** & Statistics & IED \\
\hline Mean & 1.0092 & Maximum & 4.24 \\
Standard Deviation & 1.10764 & Skewness & 0.980 \\
SE Mean & 0.1029 & SE Skewness & 0.187 \\
Minimum & 0.00 & Kurtosis & 0.281 \\
Median & 1.000 & SE Kurtosis & 0.373 \\
& & & \\
\hline
\end{tabular}

The dependent variable in this study was IED. This variable was measured by using 36 items, which represent the environmental disclosure index. The items were extracted from previous studies and consist of environmental activities and issues such as general environmental considerations and statements, environmental policy, environmental audit, environmental finance related data, environmental litigation, pollution, environmental activities, recycling and associated energy saving, and current expenditure for pollution control equipment and facilities. The score is 1 if the item exists and 0 if vice versa.

The frequency of each item is presented in Table 3. It can be seen from the table that the most common disclosed environmental items are general environmental consideration and statements $(51.5 \%)$, environmental product and process related $(22.2 \%)$, and environmental policy statement (20.6\%). However, critical items such as financing for pollution control equipment or facilities; past and current expenditure for pollution control equipment and facilities; future and current expenditure for pollution control equipment and facilities; and future and current operating costs of pollution control equipment and facilities are least provided - only 1.0 to $1.5 \%$ of companies disclose such information. It is argued that this phenomenon is due to the absence of mandatory environmental reporting standards in Malaysia. Without statutory requirement, IED will lack uniformity and value-added information. In this case, the companies can report what they want to report regardless of users' needs. To overcome this problem, it is suggested that the Malaysian Institute of Accountants, Malaysian Accounting Standards Boards, and Security Commission establish environmental reporting standards. It is expected that such statutory requirements lead to more standardised reporting practices, user friendly standards, and better enforcement. 
Table 3: Internet Environmental Disclosure Index

\begin{tabular}{clcccccc}
\hline No. & $\begin{array}{c}\text { Environmental } \\
\text { items }\end{array}$ & $\begin{array}{c}\text { Frequency } \\
\text { Percentage }(\%)\end{array}$ & N & $\begin{array}{c}\text { Environmental } \\
\text { Items }\end{array}$ & Frequency & Percentage $(\%)$ \\
\hline 1 & GES & 100 & 51.5 & 18 & DEPUL & 16 & 8.2 \\
& EP\&P & 43 & 22.2 & 19 & EFRTREN & 16 & 8.2 \\
2 & EPS & 40 & 20.6 & 20 & R\&EN & 15 & 7.7 \\
3 & EACTV & 36 & 18.6 & 21 & UTIW & 14 & 7.2 \\
4 & EMAN & 30 & 15.5 & 22 & IMSTU & 14 & 7.2 \\
5 & WTS & 29 & 15 & 23 & EAU & 13 & 6.7 \\
6 & AWAD & 26 & 13.4 & 24 & ENEFF & 11 & 5.7 \\
7 & ELOW & 26 & 13.4 & 25 & R\&D & 10 & 5.2 \\
8 & SUST & 26 & 13.4 & 26 & ENCON & 10 & 5.2 \\
9 & W\&R & 25 & 12.9 & 27 & IPE & 9 & 4.6 \\
10 & EAEST & 23 & 11.9 & 28 & RENCON & 6 & 3.1 \\
11 & POLU & 23 & 11.9 & 29 & IEPR & 6 & 3.1 \\
12 & REHB & 23 & 11.9 & 30 & ELITIG & 5 & 2.6 \\
13 & EMPW & 22 & 11.3 & 31 & FINPOL & 5 & 2.6 \\
14 & LNDR & 22 & 11.3 & 32 & P\&COC & 5 & 2.6 \\
15 & EEPRG & 21 & 10.8 & 33 & P\&CEX & 2 & 1.0 \\
16 & EFIN & 18 & 9.3 & 34 & F\&CEX & 2 & 1.0 \\
17 & SPACT & 17 & 8.8 & 35 & F\&COC & 2 & 1.0 \\
\hline
\end{tabular}

- GES: General environmental consideration and statements

- EPS: Environmental policy statement

- EAU: Environmental audit

- EMAN: Environmental manager/ committee

- ELOW: Environmental law

- EP \& P: Environmental product and process related

- EFIN: Environmental finance related data

- EAEST: Environmental aesthetics (facilities, art, restoration)

- ELITIG: Environmental litigation

- E EPRG: Environmental education programmes

- EMPW: Employee awareness of environmental policy

- EACTV: Environmental activities

- POLU: Pollution

- REHB: Rehabilitation

- W \& R: Waste and recycling

- IMSTU: Impact studies

- WTS: Water treatment system

- SUST: Sustainability

- R \& D: Research and development

- DEPUL: Departments or offices for pollution control

- IEPR: International environmental programme

- ENCON: Energy conversion

- ENEFF: Energy efficiency

- EFRTREN: Efforts to reduce energy consumption

- IPE: Increasing of product efficency

- RENCON: Research energy conservation
- AWAD: Awards

- SPACT: Support for public or private action designed to protect the environment

- LNDR: Land reclamation and forestation programmes

- FINPOL: Financing for pollution control equipment or facilities

- P \& CEX: Past and current expenditure for pollution control equipment and facilities

- P \& COC: Past and current operating costs of pollution control equipment and facilities

- F \& CEX: Future and current expenditure for pollution control equipment and facilities

- F \& COC: Future and current operating costs of pollution control equipment and facilities
Another possible reason behind poor IED amongst Malaysian listed companies is lack of knowledge amongst Malaysian accountants. The accountants may see environmental accounting as not within their jurisdiction. To alleviate this problem, an extensive training on environmental accounting treatment should be provided by the Malaysian Institute of Accountants and Malaysian Institute of Certified Public Accountants.

\section{RESULTS}

Multiple regression analysis was utilised to test the hypotheses. This was undertaken after running quality tests for collected data, namely normality, correlation analysis, and multicollinearity tests. The results from the regression showed that there are several variables that have significant positive relationships with IED. These variables are internationality, foreign shareholders, level of technology, firm age, number of shareholders, and listing status. However, the variables of dominant personalities on the board of committees and leverage do not show any significant relationship with IED. Table 4 presents the results of multiple regression analysis. 
Table 4: Multiple Regression Analysis of Determinants of Internet Environmental Disclosure

\begin{tabular}{|c|c|c|c|c|}
\hline Independent Variables & Predicted Sign & Coefficients & t-statistics & VIF \\
\hline \multicolumn{5}{|l|}{ Dominants personality in board committees } \\
\hline Chairman company and audit committee & $?$ & -0.057 & -0.605 & 2.518 \\
\hline Chairman of audit and nomination committee & ? & -.0 .024 & -0.236 & 2.952 \\
\hline Chair. com, audit and nomination committees & $?$ & 0.107 & 1.554 & 1.327 \\
\hline \multicolumn{5}{|l|}{ Company characteristics } \\
\hline Internationality & + & 0.134 & $2.173 * *$ & 1.064 \\
\hline Leverage & - & 0.117 & 1.939 & 1.029 \\
\hline Foreign shareholders & + & 0.185 & $2.900 * * *$ & 1.146 \\
\hline Level of technology & + & 0.354 & $5.649 * * *$ & 1.102 \\
\hline Firm age & + & 0.169 & $2.634 * * *$ & 1.160 \\
\hline No of shareholders & + & 0.167 & $2.578 * *$ & 1.182 \\
\hline Listing status & + & 0.309 & $4.695 * * *$ & 1.216 \\
\hline \multicolumn{5}{|l|}{ Constant } \\
\hline ANOVA & & 0.000 & & \\
\hline Durbin Watson & & 1.727 & & \\
\hline Std.Error & & 0.83739 & & \\
\hline F Value & & 12.569 & & \\
\hline Sig. F & & 0.000 & & \\
\hline R Square & & 0.448 & & \\
\hline Adjust R Square & & 0.412 & & \\
\hline
\end{tabular}

$* * *$ significant at $1 \%$ level $* *$ significant at $5 \%$ level

In addition, the productive ability of the analysis was $\mathrm{R}^{2}=448$ and Adjusted $\mathrm{R}^{2}=.412$ which is respectable. Based on the findings of Table 3 , it was declared that hypotheses $\mathrm{H} 4, \mathrm{H} 6, \mathrm{H} 7, \mathrm{H} 8$, $\mathrm{H} 9$, and $\mathrm{H} 10$ are accepted. However, hypotheses $\mathrm{H} 1, \mathrm{H} 2, \mathrm{H} 3$, and $\mathrm{H} 5$ are rejected. Nevertheless, information disclosure involves human judgment and therefore cannot be solely explained by the company's characteristics. This paper, however, provides some evidence to support signaling theory, shareholder accountability theory, and cost and benefit hypothesis in relation to disclosure.

\section{DISCUSSION OF RESULTS}

\section{Dominant Personality in Board Committees}

As mentioned in the above discussion, this group of variables is a new group and has never been tested before. The regression results showed that none of the variables of dominant personalities on the board committees show a significant relationship with the extent of IED. This result maybe due to the role of board committees being not clear in terms of environmental disclosure.

\section{Company Characteristics}

From the regression analysis, all the variables that represent company characteristics showed positive significant relationships with IED, except leverage. These variables are internationality, foreign shareholders, level of technology, company age, number of shareholders, and listing status. More details about these relationships and their justifications are provided in the following paragraphs.

The variable of internationality has a significant positive relationship with IED. This result is in tandem with the initial expectation that international companies are more concern with the environment and therefore disclose more environmental information on their websites. This information includes environmental activities and how their products are environmental friendly. This in turn supports the legitimacy theory that states that the companies have to undertake some aggressive steps so that their activities and performances can be accepted by the community (Patten, 1991, 1992; Patten \& Trompeter, 2003; Deegan \& Rankin, 1996; Wilmshurst \& Frost, 2000). Nowadays, people tend to avoid buying products that harm the environment (Shanka \& Gopalan, 2005). 
The findings also indicated that there is a significant positive relationship between foreign shareholders and the extent of IED in Malaysia. The results lend support to the argument that higher foreign shareholding leads to higher asymmetry information, and eventually leads to higher financial and environmental disclosures (Xiao et al., 2004). In addition, as environmental issues are given serious attention by many companies in the world, the increase in environmental information requirement from foreign shareholders is unquestionable. Hence more information is required to mitigate that perception. This could be achieved through extensive voluntary disclosure. On the other hand, global dissemination of financial and environmental information is necessary to create greater transparency, which might be important to foreign investors (Isenmann \& Lenz, 2001).

This research also obtained a positive relationship between level of technology and the extent of IED. This result was as expected because internet reporting requires the companies to acquire relevant technologies and establish a department that is responsible for maintaining the website. Although the cost for internet disclosure is low in comparison to printed media, but it has other operational costs such as setting up the website design, maintaining files and software, uploading information, updating information, and maintaining the website. All these costs discourage the companies from having their own website (Lodhia, 2004). Therefore, if the company has a department to handle its website and acquire necessary technologies for internet reporting, a high level of IED is considered logical. In short, having necessary tools and an information system department can spur IED. This argument is consistent with previous studies (Debreceny et al., 2002).

The variable of company age also has a significant positive relationship with IED. This positive relationship can be explained by the signaling theory which stipulates that old companies are generally disclosing more information in order to differentiate themselves from the new comer on the stock exchange (Morris, 1987; Watts \& Zimmerman, 1986; Skinner, 1994). Another possible explanation is that old companies are more experienced in both environmental issues and internet usage. This phenomenon is driven by the need to maintain market dominance and to please the public and investors. Besides its dominance in the market, old companies are always under public scrutiny. In short, it is logical to observe a high level of IED amongst old Malaysian listed companies. The finding is similar to that of Cormier and Magnan (2004).

The fifth identified variable was number of shareholders. It shows a significant positive relationship with IED. This result supported the shareholder accountability theory which states that the management has to fulfill the shareholders' demand in order to avoid accountability inquisition. It is logical to observe this phenomenon because the Internet has wide coverage and low reporting cost compared to other printed media. In other words, the companies that have a large number of shareholders prefer to exploit the advantages of internet technology to disclose environmental information due to the following reasons:

- to ensure equal access to companies' environmental activities amongst shareholders,

- to respond to different shareholders' needs in relation to environmental information, and

- to reduce costs because environmental information has its preparation and dissemination costs.

The last variable that shows a significant positive relationship with IED was listing status. This variable is a new variable and has never been tested in previous studies. The results of regression analysis indicated that if the companies are listed on the main board of Bursa Malaysia, they are inclined to have websites and disclose more environmental information on them compared to the companies that are listed on the second board. In other words, there is a gap between the companies that are listed on the main board and the companies that are listed on the second board. This gap in turn influences the level of transparency and the usage of advanced technology such as 
the Internet. Nevertheless, it is not surprising to observe this phenomenon because of different requirement of Bursa Malaysia in relation to main and second boards. This is because the main board consists of large organisations (financial capital of more than RM60 million) and therefore capture more public and government concern in relation to the level of transparency, technology development, and environment. This results in the policy makers of Bursa Malaysia to set more stringent requirements and regulations for main board companies. Internet reporting is an option to fulfill all the requirements in a cheap and fast manner.

To recapitulate, the above six variables were critical in determining the level of IED amongst Malaysian listed companies. Therefore, Malaysian government should examine as to whether the involved variable information has been shared with the companies or not. This could be translated into action by imposing relevant rules and regulations. Stringent action should be taken on the companies that fail to comply with the imposed rules and regulations.

\section{Conclusion and Future Research}

This paper examined the relationship between 10 variables and the extent of IED by Malaysian listed companies. The results provided evidence that there is a significant positive relationship between internationality, foreign shareholders, level of technology, firm age, number of shareholders, and listing status and the level of IED. The rest of variables do not show any significant relationship with IED. Therefore, it is recommended that the Malaysian government should give more consideration to these determinants and impose new regulations so that IED can be improved in the future. The study also observed a transparency gap between the main and second board of listed companies.

It can be concluded that, there are several measures that the Malaysian government, policy makers, and regulatory authorities can take in order to enhance the level of transparency amongst Malaysian listed companies. By considering the above significant independent variables, it is argued that Malaysian companies can be motivated to be more transparent and sensitive to information technology. The regulatory bodies can also impose necessary rules and regulations to obligate the companies to take advantages of internet technology. This step seems to be useful in realising vision 2020, which is to turn Malaysia into a developed nation.

\section{REFERENCES}

Abdul Samad, F. (2002). Ownership structure in the Malaysian corporation sector: Its impact on corporate governance, performance, financing and investment patterns. Institute for Development Policy and Management Working Paper (University of Manchester).

ACCA (2005). Sustainability reporting guidelines for Malaysian companies. The Association of Charted Certified Accountants.

Ahmad Z., Hassan, S., \& Mohammad, J. (2003). Determinants of environmental reporting in Malaysia. International Journal of Business Studies, 1(11), 69-81.

Ahmed, A., Billings, B., Morton, R., \& StanfordHarris, M. (2002). The role of accounting conservatism in mitigating bondholdershareholder conflicts over dividend policy and in reducing debt costs. The Accounting Review, 77(4), 867-890.

Ahmed, K., \& Nicholls, D. (1994). The impact of non-financial company characteristics on mandatory disclosure compliance in developing countries: The case of Bangladesh. The International Journal of Accounting, 29(1), 62-77.

Alsaeed, K. (2005). The association between firmspecific characteristics and disclosure: The case of Saudi Arabia. Managerial Auditing Journal, 21(5), 476-489.

Al-Tuwaijria, S.A, Christensenb, T.E., \& Hughes, K.E. (2003). The relations among environmental disclosure, environmental performance, and economic performance: A simultaneous equations approach. King Fahd University of Petroleum and Minerals. 
Andrew, J. (2003). Corporate governance, the environment, and the internet. Electronic Green Journal. Retrieved: from http:// egj.lib.uidaho.edu/egj19/andrew1.html

Blue Ribbon Committee (1999). Report and recommendations of the blue ribbon committee on improving the effectiveness of corporate audit committees. New York: New York Stock Exchange.

Camfferman, K., \& Cooke, T.E. (2002). An analysis of disclosure in the annual reports of UK and Dutch companies. Journal of International Accounting Research, 1(1), 3-30.

Chow, C.W., \& Boren, W.A. (1987). Voluntary financial disclosure by Mexican corporations. The Accounting Review, 62(3), 533-541.

Cooke, T.E. (1989). Disclosure in the corporate annual reports of Swedish companies. Accounting and Business Research, 19(74), 113-124.

Cormier, D., \& Magnan, M. (2004). The impact of the web on information and communication modes: The case of corporate environmental disclosure. International Journal of Technology Management, 27(4), 393-416.

Debreceny, R., Gray, G.L., \& Rahman, A. (2002). The determinants of internet financial reporting. Journal of Accounting and Public Policy, 21(4\&5), 371-394.

Deegan, C., \& Rankin, M. (1996). Do Australian companies report environmental news objectively? An analysis of environmental disclosures by firms prosecuted successfully by the Environmental Protection Authority. Accounting, Auditing and Accountability Journal, 9(2), 50-67.

Dichev, L., \& Skinner, D. (2002). Largesample evidence on the debt covenant hypothesis. Journal of Accounting Research, 40(4), 1091-1124.

Dunlap, R.E., \& Scarce, R. (1991). Poll trends: Environmental problems and protection. Public Opinion Quarterly, 55(4), 651672.
Esrock, S.L., \& Leichty, G.B. (1998). Social responsibility and corporate web pages: Self-presentation or agenda setting. Public Relations Review, 24(3), 305-319.

Ettredge. M., Richardson, V.J., \& Scholz, S. (2002). Timely financial reporting at corporate websites. Communications of the ACM, 6(45).

Garcia-Benau, M.A., \& Monterrey-Mayoral, J. (1992). Voluntary financial disclosure by listed Spanish companies: Extent and corporate characteristics. Paper presented at the 15th EAA Congres, Madrid.

Gray, S.J., Meek, G.K., \& Roberts, C.B. (1994). International capital market pressures and voluntary disclosure decisions by USA, UK, and Continental European multinationals. Paper presented at the 17th Annual Congress of the European Accounting Association, Venice.

Groff, J.E., \& Pitman, M.K. (2004). Municipal financial reporting on the world wide web: A survey of financial data displayed on the official websites of the 100 largest USA municipalities. The Journal of Government Financial Management, 2(53), 2-22.

Gul, F.A., \& Leung, S. (2004). Board leadership, outside directors' expertise and voluntary corporate disclosures. Journal of accounting and Policy, 23(5), 351-379.

Guthrie, J., \& Turnbull, S. (1995). Audit committees: Is there a role for corporate senates and/or stakeholders councils. Corporate Governance: An International Review, 3(2), 78-89.

Haniffa, R., \& Cooke, T. (2002). Culture, corporate governance and disclosure in Malaysian Corporations. ABACUS, 38(3), 317-349.

Hassan, A., Jaffer, N., \& Johi, S.K. (1999). Financial reporting on the internet by Malaysian companies: Perceptions and practices. Asia-Pacific Journal of Accounting, 6(2), 299-319.

Healy, P.M., \& Palepu, K.G. (2001). Information asymmetry, corporate disclosure, and the capital markets: A review of the 
empirical disclosure literature. Journal of Accounting and Economics, 31(1-3), 405-440.

Ho, S.S.M., \& Wong, S.K. (2001). A study of the relationship between corporate governance structures and the extent of voluntary disclosure. Journal of International Accounting, Auditing and Taxation, 10(2), 139-156.

Hoggett, J., \& Nahan, M. (2002). The financial services reform act - A costly exercise in regulating corporate morals. IPA Backgrounder, 14(1).

Houlston., E., \& Daoust., C. (2005). Victoria's cruise ship industry: Economic benefits and their environmental impacts. Vancouver Island Public Interest Research Group Working Paper.

Hughes, P.J. (1986). Signalling by direct disclosure under asymmetric information. Journal of Accounting and Economics, 8(2), 119-142.

Isenmann, R., \& Lenz, C. (2001). Customized corporate environmental reporting by internet-based push and pull technologies. Management and Auditing, 8(2), 100-110.

Jensen, M.C., \& Meckling, W.H. (1995). Specific and general knowledge, and organizational structure. Journal of Applied Corporate Finance, 2(8), 4-18.

Jones, K., Alabaster, T., \& Hetherington, K. (1999). Internet-based environmental reporting: Current trends. Greener Management International 1(26), 69-90.

Katsuhiko, K., Akihiro, N., Yasushi, O., \& Tomomi, S. (2001). Determinants of Environmental Report Publication in Japanese Companies. Paper presented at the 3rd APIRA conference, Adelaide.

Kesner, I.F. (1988). Directors' characteristics and committee membership: An investigation of type, occupation, tenure, and gender. The Academy of Management Journal, 31(1), 66-84.

Klein, A. (2002). Audit committee, board of director characteristics, and earnings management. Journal of Accounting and Economics, 33(3), 375-400.
Laswad, F., Fisher, R., \& Oyelere, P. (2005). Determinants of voluntary Internet financial reporting by local government authorities. Journal of Accounting and Public Policy, 24(2), 101-121.

Lev, B., \& Zarowin, P. (1999). The boundaries of financial reporting and how to extend them. Journal of Accounting Research, 37(2), 353-383.

Lindblom, B., MacNeilage, P., \& StuddertKennedy, M. (1984). Self-organizing processes and the explanation of phonological universals. Explanations for Language Universals, 181203.

Lodhia, S.K. (2002). Corporate environmental reporting and accountability to external stakeholders: A case for world wide web technology. Paper presented at the Accountability Interest Group Symposium, Sheraton Hotel, Perth.

Lodhia, S.K. (2004). Corporate environmental reporting media: A case for the world wide web. Electronic Green Journal, 1(20).

Malaysian Accounting Standard Board, (MASB) (1999). MASB Standard 1 Presentation of Financial Statements. Kuala Lumpur: Malaysian Accounting Standard Board.

Marston, C. (2003). Financial reporting on the internet by leading Japanese companies. Corporate Communications: An International Journal, 8(1), 23-34.

Marston, C., \& Polei, A. (2004). Corporate reporting on the internet by German companies. International Journal of Accounting Information Systems, 5(3), 285- 311.

McIvor, R., McHugh, M., \& Cadden, C. (2002). Internet technologies: Supporting transparency in the public sector. International Journal of Public Sector Management, 15(3), 170-187.

McMullen, D.A. (1996). Audit committee performance: An investigation of the consequences associated with audit committees. Auditing: A Journal of Practice and Theory, 15(1), 87-103.

Meek, G.K., \& Thomas, W.B. (2003). A review of markets-based international accounting 
research. Oklahoma State University Working Paper.

Morris, R.D., \& Gray, S.J. (2005). Corporate transparency in China: Factors influencing financial disclosure levels. Paper presented at the 29th Annual Congress of the European.

Morris, R.D. (1987). Signaling, agency theory and accounting policy choice. Accounting and Business Research, 18(69), 47-56.

Nik Ahmad, N.N., Sulaiman, M., \& Siswantoro, D. (2003). Corporate social responsibility disclosure in Malaysia: An analysis of annual reports of KLSE listed companies. Journal of Economics and Management, 11(1), 1-37.

Oyelere, P., Laswad, F., \& Fisher, R. (2003). Determinants of internet financial reporting by New Zealand companies. Journal of International Financial Management and Accounting, 14(1), 26-63.

Park, J. (1999). A study on navigational support technologies in web-based adaptive courseware design. Journal of Educational Technology, 15(1), 65-90.

Patten, D.M. (1991). Exposure, legitimacy, and social disclosure. Journal of Accounting and Public Policy, 4(10), 297-308.

Patten, D.M. (1992). Intra-industry environmental disclosure in response to the Alaskan oil spill: A note on legitimacy theory. Accounting, Organizations, and Society, 5(17), 471-476.

Patten, D.M., \& Trompeter, G. (2003). Corporate responses to political costs: An examination of the relation between environmental disclosure and earnings management. Journal of Accounting and Public Policy, 22(1), 83-94.

PriceWaterhouseCoopers (2000). Press Release - Business Wire.Vancouver.

Raffournier, B. (1995). The determinants of voluntary financial disclosure by Swiss listed companies. The European Accounting Review, 4(2), 261-280.

Ramasamy, B., \& Ting, H.W. (2004). A comparative analysis of corporate social responsibility awareness: Malaysia and Singaporean firms. The Journal of Corporate Citizenship, 13(1), 109-123.

Richardson, A.J., \& Welker, M. (2001). Social disclosure, financial disclosure and the cost of equity capital. Accounting Organizations and Society, 26(7), 597616.

Roberts (1992). Determinants of corporate social responsibility disclosure: An application of stakeholder theory. Accounting, Organizations and Society, 17(6), 595612.

Sarbanes-Oxley Act (2002). One hundred seventh congress of the United States of America (2nd session). Washington D.C.

Sekaran, U. (2002). Research methods for business: A skill building approach (4th ed.). Singapore: John Wiley \& Sons.

Shanka, T., \& Gopalan, G. (2005). Socially responsible consumer behavior-higher education students' perceptions. Paper presented at the Conference of Corporate Responsibility. ANZMAC.

Skinner, D.J. (1994). Why firms voluntary disclose bad news. Journal of Accounting Research, 32(1), 38-60.

Sriram, R.S., \& Laksmana, I. (2006). Corporate website reports: Some evidence on relevance and usefulness. Information Resources Management Journal, 19(3), $1-28$.

Suda, K., \& Kokubu, K. (1994). Some determinants of environmental disclosure in Japanese companies. Corporate Social Disclosure Work paper.

Thompson, P. (2002). Corporate environmental reporting in Singapore and Malaysia: Progress and prospects. Centre for Europe-Asia Business Research (Research Paper).

Thompson, P., \& Zakaria, Z. (2004). Corporate social responsibility reporting in Malaysia: Progress and prospects. The Journal of Corporate Citizenship Sheffield, 13(1), 125-136.

Tilt, C.A. (2001). Environmenal disclosure by Australian companies: What is happening outside the annual report? Paper presented at the Proceedings of the 
Asia Pacific Interdisciplinary Research in Accounting (APIRA) Conference.

Wagenhofer, A. (2003). Economic consequence of internet financial reporting. Schmalenbach Business Review, 55(4), 262-279.

Watts, R.L., \& Zimmerman, J.L. (1986). Positive accounting theory. Englewood Cliffs, New Jersey: Prentice-Hall.

Wilmshurst, T.D., \& Frost, G.F. (2000). Corporate environmental reporting: A test of legitimacy theory. Accounting, Auditing, and Accountability Journal, 13(1), 1026.

Wong, N.L. (1996). Easing down the meritdisclosure continuum: A case study of Malaysia and Taiwan. Law and Policy in International Business, 28(1) 24-39.
Xiao, J.Z., Yang, H., \& Chow, C.W. (2004). The determinants and characteristics of voluntary internet-based disclosures by listed Chinese companies. Journal of Accounting and Public Policy, 23(3), 191-225.

Xie, B., Wallace, N.D., and Peter, D. (2003). Earnings management and corporate governance: The role of board and the audit committee. Journal of Corporate Finance, 9(3), 295-316.

Yatim, P., Kent, P., \& Clarkson, P. (2006). Governance structures, ethnicity, and audit fees of Malaysian listed firms. Managerial Auditing Journal, 21(7), 757-782.

Zulkifli, N. (2003). Realizing corporate social and environmental responsibility in Malaysia: Perceptions and realities. Kuala Lumpur: University of Malaya Press. 